\title{
Pengalaman Ibu Remaja Primipara Memperoleh Dukungan Keluarga Dalam Memberikan ASI Eksklusif
}

\author{
Rini Rahmayanti ${ }^{1}$, Setyowati $^{2}$, Yati Afiyanti ${ }^{3}$ \\ 1) Rini Rahmayanti: STIKes MERCUBAKTIJAYA Padang. \\ Jln Jamal Jamil Pondok Kopi Siteba Padang, Sumatera Barat \\ 2),3) Departemen Keperawatan Maternitas Fakultas Ilmu Keperawatan Universitas Indonesia \\ E-mail: rinie.rahmayanti@gmail.com
}

\begin{abstract}
Abstrak
Dukungan keluarga merupakan hal penting dalam meningkatkan kepercayaan diri ibu remaja. Hal ini terkait dengan kondisi ibu remaja yang rentan dan membutuhkan bimbingan. Penelitian kualitatif ini menggunakan desain fenomenologi melalui wawancara mendalam terhadap delapan orang ibu remaja dengan tematik konten analisis. Penelitian ini menghasilkan tujuh tema yaitu ibu remaja mempunyai persepsi yang baik tentang ASI eksklusif, sebagian besar partisipan mengalami masalah fisik dan psikologis karena kurangnya pengetahuan dan dukungan, dukungan suami dan orangtua serta anggota keluarga perempuan sangat diperlukan untuk keberhasilan ASI eksklusif, bentuk dukungan keluarga yang dirasakan bermanfaat adalah dukungan instrumen, informasi, emosi dan penghargaan. Partisipan merasakan peningkatan kepercayaan diri untuk menyusui karena adanya dukungan keluarga. Beberapa partisipan merasakan kendala dalam menyusui berupa perbedaan informasi dan anjuran dari keluarga yang tidak sesuai harapan. Tetapi partisipan tetap mengikuti arahan ibu kandung untuk mempertahankan pemberian ASI eksklusif. Hasil temuan ini merekomendasikan kepada perawat maternitas untuk mengoptimalkan peran dan pengawasan terhadap ibu remaja dimulai dari masa antenatal dengan melibatkan keluarga.
\end{abstract}

Kata kunci: dukungan keluarga, ibu remaja, ASI eksklusif.

\begin{abstract}
Family support is important to increase the self confidence of teenage mothers. It's associated with teenage mothers are vulnerable and need of guidance. This qualitative research was used a phenomenology design, that interviewed eight teenage mothers. Thematic content analysis were used in analyzied the result. Seven themes were produced in this study namely; Good perception of exclusive breastfeeding amongst teenage mothers. Most of participants had physical and psychological problems due to lack of knowledge and supports. Partners and parents supports are needed in order to success exclusive breastfeeding. The type of supports that need are informational, reward, instrumental, and emotional support from the family. Participants feel that their self confidence increased to breastmilk when they get support from their family. Some participants faced problems in giving breastmilk to their baby due to wrong information and wrong advice from family. Participants tried to follow the direction of their mother in order to obtain the exclusive breastfeeding. The findings recommended to maternity nurse to optimize their role and monitoring in teenage mothers starting from the antenatal period by involving her family.
\end{abstract}

Key words: family support, teenage mother, exclusive breastfeeding

\section{PENDAHULUAN}

Menjadi orangtua menciptakan periode ketidakstabilan yang menuntut perilaku transisi. Ibu dengan usia remaja akan menghadapi berbagai kesulitan seperti ketidakcukupan ekonomi dan pendidikan serta beresiko mengalami kekerasaan dalam rumah tangga (Kleiber \& Dimidjian, 2014). Ibu remaja mempunyai peran yang sangat penting dalam hal peningkatan status kesehatan khususnya dalam hal pemantauan pertumbuhan dan perkembangan pada bayi. 
Pemberian ASI eksklusif merupakan salah satu cara peningkatan status kesehatan bayi.

Memberikan ASI eksklusif merupakan tanggungjawab baru ibu remaja setelah melahirkan. Tetapi tugas baru ini sering berdampak pada psikologis ibu remaja. Kurangnya pengetahuan dan pengalaman praktek menyusui seperti berapa frekuensi menyusui, apakah tanda saat bayi sudah cukup menyusui dapat menyebabkan frustasi dan mudah menyerah pada ibu remaja (Nesbitt et al, 2012).

Faktor yang mendukung ibu remaja dalam pemberian ASI antara lain dukungan dari tenaga professional dan keluarga untuk mengatasi kesulitan dan menyusui. Beberapa alasan yang diungkapkan terkait ibu remaja berhenti menyusui adalah karena nyeri pada puting, kesulitan perlengketan dan ASI sedikit, serta ibu kembali ke sekolah (Tucker, Wilson, \& Samandari, 2011). Dukungan yang masih kurang dari keluarga menjadi salah satu penyebab kegagalan ASI eksklusif oleh ibu remaja.

Dukungan keluarga merupakan sikap, tindakan, dan penerimaan keluarga terhadap anggota keluarga yang mengalami masalah kesehatan (Friedman, 2003). Dukungan keluarga berupa pemberian informasi, pemberian instrumen yang mendukung, dukungan emosional (pemberian perhatian dan kasih sayang) serta pemberian penghargaan. Anggota kelurga seperti ibu, nenek, saudara perempuan, bibi dilaporkan sebagai pemberi dukungan yang paling besar bagi ibu remaja (Schrag \& Schmidt-tieszen, 2014).

Di Indonesia pemberian ASI eksklusif oleh ibu remaja belum terdokumentasi dengan baik. Secara umum, Provinsi Jawa Barat merupakan salah satu provinsi yang memiliki capaian ASI esklusif di bawah rata-rata nasional (33,7\%) (Pusdatin, 2014). Kabupaten Bogor merupakan wilayah tertinggi cakupan ASI eksklusif (54\%) dibanding wilayah lain. Wilayah kerja Puskesmas Tajur Halang dan Puskesmas Kemuning merupakan wilayah tertinggi jumlah ibu remaja di Kec. Bojong Gede. Di Puskesemas Tajur Halang, jumlah bayi yang dilahirkan oleh ibu remaja pada tahun 2014 adalah 30 per 260 orang, $35 \%$ diantaranya mendapatkan ASI eksklusif (Data Puskesmas Tajur Halang, 2014). Salah satu faktor yang mempengaruhi pemberian ASI di daerah ini adalah dukungan keluarga. Sehingga perlu dilakukan studi yang lebih mendalam mengenai bagaimana pengalaman ibu remaja primipara dalam memperoleh dukungan keluarga dalam memberikan ASI eksklusif.

\section{METODE PENELITIAN}

Penelitian fenomenologi deskriptif ini melibatkan delapan orang ibu remaja yang dipilih dengan teknik purposive sampling di wilayah kerja Puskesmas Kemuning dan Puskesmas Tajur Halang Kabupaten Bogor. Sampel terdiri dari ibu remaja primipara yang memberikan ASI eksklusif, kisaran usia 12-18 tahun, mempunyai bayi berusia diatas enam bulan dan dibawah 24 bulan, bersedia menjadi partisipan dengan menandatangani lembar persetujuan, mampu berbahasa Indonesia, mampu menceritakan dengan lancar pengalamannya dalam memperoleh dukungan keluarga. Penelitian ini telah mendapatkan ijin etik dari komite etik Fakultas Ilmu Keperawatan Universitas Indonesia.

Metode pengumpulan data dengan wawancara mendalam (indepth interview). Wawancara dilakukan dengan pertanyaan terbuka. alat pengumpul data yang digunakan antara lain diri peneliti sendiri secara personal, pedoman wawancara, catatan lapangan dan alat perekam. Jumlah kunjungan yang dilakukan sebanyak tiga sampai empat kali untuk tiap partisipan sehingga sesuai dengan ketercapaian tujuan penelitian.

\section{HASIL DAN PEMBAHASAN}

Karakteristik usia didapatkan rentang usia partisipan antara 16-18 tahun, pendidikan partisipan terdiri SD dan SLTP, semua partisipan berstatus menikah dan tidak bekerja (IRT), anggota keluarga yang serumah bervariasi yaitu suami, orangtua, adik dan 
mertua. Karakteristik usia bayi sekarang mulai dari usia 7 bulan hingga 23 bulan. Semua partisipan memberikan makan/minum saat bayi berusia enam bulan ke atas. Karakteristik tempat persalinan terdiri dari dua partisipan melahirkan di puskesmas, empat orang partisipan melahirkan di RS, dan dua orang partisipan melahirkan di praktik bidan. Karakteristik jenis persalinan didapatkan lima orang partisipan melahirkan normal dan tiga orang partisipan melahirkan dengan operasi Caesar.

Penelitian ini menghasilkan tujuh tema utama.

Tema pertama; Ibu remaja mempunyai persepsi yang baik tentang ASI eksklusif

empat partisipan menyatakan pemahamannya tentang ASI eksklusif adalah ASI yang diberikan pada bayi sampai usia enam bulan tanpa dikasih apapun. tujuh partisipan menjelaskan persepsinya bahwa ASI berguna untuk kesehatan anak. Dua partisipan menyatakan ASI bermanfaat untuk diri ibu sendiri. Tiga partisipan mengungkapkan ASI meningkatkan kedekatan antara ibu dan anak. Tema ini tergambar dari pernyataan partisipan sebagai berikut

"...ASI eksklusif, asi yang diberikan pada bayi sampai usia enam bulan tanpa dikasih apapun, Cuma ASI aja, murn ya.. ASI murni ya..." (P1)

Tema kedua; Partisipan mengalami masalah fisik dan psikologis karena kurangnya pengetahuan dan dukungan

Enam partisipan menceritakan hambatan selama memberikan ASI eksklusif adalah masalah fisik, Lima partisipan menyatakan masalah psikologis, Dua partisipan mengungkapkan kurang pengetahuan dan Lima partisipan mengungkapkan kurang dukungan keluarga. Tema ini tergambar dari pernyataan partisipan sebagai berikut

“..Saya awalnya bingung ya mbak, saya ga ngerti harus ngapain. Walau pun selama hamil udah dikasih tau tapi tetep saya kagok, ga ngerti..” (P4)
Tema ketiga; Dukungan suami dan orangtua serta anggota keluarga perempuan sangat diperlukan untuk keberhasilan ASI eksklusif

Pasangan merupakan salah seorang sumber dukungan diungkapkan oleh tiga orang partisipan. Lima partisipan menyatakan ibu kandung, Satu partisipan mengatakan mendapat dukungan dari ayah. Satu partisipan menyebutkan mertua sebagai sumber dukungan. Satu orang partisipan menyebutkan kakak perempuan. Tema ini tergambar dari pernyataan partisipan sebagai berikut

"...Suami kalau kata aku sih suami siaga bangetlah, orang yang paling mendukung..." (P3)

Tema keempat; Bentuk dukungan keluarga yang dirasakan bermanfaat adalah dukungan instrumen, informasi, emosional dan penghargaan

Salah satu bentuk dukungan adalah dukungan instrumen menurut tiga orang partisipan, enam partisipan mengungkapkan dukungan informasi, lima partisipan menyatakan dukungan emosional dan empat partisipan mengungkapkan salah satu dukungan yang didapat dari keluarga adalah dukungan penghargaan. Tema ini tergambar dari pernyataan partisipan sebagai berikut

“...Kalau kesini dia (kakak perempuan) sering bawain makanan juga, sayur-sayuran juga, "...Buah-buahan juga sering dibeliin, vitamin juga...”(P3)

\section{Tema kelima; Partisipan merasakan kendala dalam menyusui berupa perbedaan informasi dan anjuran dari keluarga yang tidak sesuai harapan}

Dukungan keluarga meningkatkan semangat dan motivasi sehingga berhasil memberikan ASI eksklusif bagi empat orang partisipan, lima partisipan mengungkapkan masalah dalam memberikan ASI teratasi, Tiga partisipan mengatakan dukungan keluarga meningkatkan rasa percaya diri. Tema ini tergambar dari pernyataan partisipan sebagai berikut 
“...Hmm...gimana ya...semua perlu bangetlah ya..berguna banget seтиa dukungannya. Kalau gak dibantuin pompa sama kompres teteknya juga gak bakal bisa ngasih ASI...pasti bengkak ga berkurang..." (P1)

Tema keenam; Partisipan merasakan kendala dalam menyusui berupa perbedaan informasi dan anjuran dari keluarga yang tidak sesuai harapan

Kendala dalam memperoleh dukungan keluarga adalah perbedaan informasi yang didapatkan oleh tiga orang partisipan, Empat partisipan menceritakan adanya dukungan keluarga yang tidak sesuai dengan harapan ibu remaja. Tema ini tergambar dari pernyataan partisipan sebagai berikut

"...tapi mbak waktu habis lahiran saya sempat kaget mbak,waktu mertua larang saya kasih ASI yang pertama itu lho..yang warna nya kuning. katanya bayi bisa mencret sebaiknya dibuang dulu. Tapi saya sebelumnya udah dengar manfaat ASI pertama itu untuk bayi dari buk bidan,,jadi saya gak ikutin kata mertua..”(P5)

\section{Tema ketujuh; Partisipan mengikuti arahan ibu kandung untuk mempertahankan pemberian ASI eksklusif}

Dua partisipan menceritakan alasannya untuk dapat mempertahankan pemberian ASI eksklusif adalah karena mendengarkan nasehat ibu berupa pengalaman memberikan makanan tambahan, tiga partisipan menyatakan ibu remaja mendengarkan manfaat ASI yang sudah terbukti. Tema ini tergambar dari pernyataan partisipan sebagai berikut

“... ya ibu kasih saran jangan pernah dikasih pisang, karena dulu pernah tu saudara seusia saya juga dikasih pisang sama kakak ibu langsung dirawat bayinya, ususnya tersumbat, ga bisa BAB berapa hari itu. akhirnya dirawat..jadinya saya takut ngasih apa-apa selain ASI..." (P5)

Ibu remaja memperoleh dukungan keluarga dari sumber yang berbeda-beda mulai dari pasangan, ibu kandung, ibu mertua kakak peremuan dan sepupu. Hal ini sejalan dengan penjelasan Schrag \& Schmidt-tieszen (2014) dan Nesbitt et al (2012) bahwa anggota kelurga seperti ibu kandung, ibu tiri, nenek, saudara perempuan dan bibi yang memiliki pengalaman menyusui sebelumnya dilaporkan sebagai pemberi dukungan yang paling besar bagi ibu remaja dalam menyusui.

Menurut Emmott \& Mace (2015), Ibu remaja sangat membutuhkan dukungan dari ibu kandung, merasa tidak mampu tanpa dukungan keluarga, pasangan dan anggota keluarga perempuan selalu mendukung dan menasehati. Dukungan pasangan dan orangtua berpengaruh terhadap keberhasilan ASI eksklusif.

Bentuk dukungan keluarga yang diterima bervariasi yaitu dukungan instrumental, informasi, emosional dan penghargaan. Hannula et al. (2008) menjelaskan bahwa dukungan yang diberikan meningkatkan efikasi diri, merasa bisa dan berdaya dalam memberikan ASI.

Dukungan instrumental yang didapatkan berupa bantuan kegiatan sehari-hari, pemenuhan kebutuhan makanan bergizi, perawatan payudara dan pemenuhan ekonomi. Dukungan informasi merupakan dukungan yang sering diterima dari keluarga. Informasi yang didapatkan antara lain informasi mengenai cara menyusui, pengalaman menyusui sebelumnya dari anggota keluarga dan cara mengatasi hambatan dalam memberikan ASI eksklusif. Dukungan emosional sebagai salah satu dukungan dari keluarga. Dukungan yang diperoleh berupa perhatian, kepedulian dan kata-kata penyemangat untuk memberikan ASI yang selalu diberikan oleh keluarga. Kehadiran pasangan berpotensi meningkatkan dukungan emosional yang berhubungan dengan meningkatnya pemberian ASI (Emmott \& Mace, 2015; Forste, 2008). Dukungan penghargaan sebagai salah satu dukungan yang diperoleh dari keluarga. Dukungan penghargaan adalah usaha untuk meningkatkan kepercayaan diri (Moran, Dykes, Burt, \& Shuck, 2006). Pemberi 
dukungan tidak boleh mengkritik praktik menyusui ibu karena hal itu dapat menurunkan rasa percaya diri. Dukungan penghargaan akan membangun kepercayaan diri ibu remaja melalui afirmasi, pemberdayaan dan penerimaan.

Ibu remaja tinggal bersama anggota keluarga yang lain (extended family) menyebabkan ibu remaja bisa mendapatkan berbagai bentuk dukungan untuk memberikan ASI eksklusif. Ibu remaja bisa mendapatkan berbagai dukungan dari keluarga karena adanya hubungan yang harmonis antar anggota keluarga. Pasangan dan anggota keluarga bekerja sama memberikan dukungan untuk meingkatkan keyakinan diri remaja untuk dapat memberika ASI eksklusif

Bentuk-bentuk dukungan yang diberikan oleh keluarga memberikan beberapa manfaat bagi ibu remaja. Dukungan yang berpusat pada keluarga merupakan salah satu bagian penting dalam strategi peningkatan keberhasilan pemberian ASI eksklusif.

Bantuan dari keluarga berupa informasi dan nasehat tentang menyusui dapat meningkatkan pengetahuan dan kesiapan ibu remaja. Dukungan dari keluarga besar berupa pengalaman menyusui di masa lalu dan pengetahuan tentang menyusui dari ibu kandung meningkatkan pengetahuan ibu remaja dalam memberikan ASI (Grassley \& Eschiti, 2008). Selain itu Masalah-masalah dalam pemberian ASI seperti payudara bengkak, putting lecet bisa teratasi dengan bantuan pengalaman masa lalu dari keluarga seperti ibu kandung dan anggota keluarga perempuan yang menyusui sebelumnya.

Dukungan yang diperoleh ibu remaja dari keluarga membentuk kepercayaan diri ibu dalam menjalankan tugas baru sebagai ibu. Kepercayaan diri ibu remaja tercermin dari adanya motivasi, kenyamanan dan rasa kasih sayang dari ibu remaja. Kepercayaan diri yang tinggi dapat meningkatkan keberhasilan pemberian ASI eksklusif oleh ibu remaja. Peningkatan kepercayaan diri setelah mendapat dukungan berupa penghargaan atau pujian dari pasangan dan orangtua. Hal ini sejalan dengan penelitian Spencer (2012) bahwa ibu remaja yang memperoleh dukungan dari ibu kandung dan pasangan berupa opini dan nasehat akan dapat meningkatkan kepercayaan diri ibu untuk memberikan IMD dan ASI eksklusif.

Manfaat dukungan yang dirasakan sejalan dengan beberapa penelitian karena keunikan ibu remaja yang secara umum belum mampu mengambil keputusan sendiri terutama dalam pemberian ASI eksklusif. Dukungan keluarga dapat meningkatkan kepercayaan diri yang biasanya mudah menyerah menghadapi kesulitan menyusui. Kepercayaan diri yang tinggi dapat meningkatkan keberhasilan pemberian ASI eksklusif oleh ibu remaja. Peningkatan kepercayaan diri setelah mendapat dukungan berupa penghargaan atau pujian dari pasangan dan orangtua.

Beberapa kendala yang dihadapi selama memperoleh dukungan keluarga kebimbangan pada ibu remaja. Perbedaan informasi muncul antar anggota keluarga seperti antara orangtua, mertua dan tante. Hal ini sesuai dengan penelitian Spencer tahun 2012 yang menjelaskan bahwa informasi yang tidak konsisten mengenai menyusui sering muncul di mulai dari tenaga kesehatan. Ibu remaja mengharapkan informasi mengenai menyusui diberikan oleh kelanjutan. Keluarga sebagai pendukung pemberian ASI di rumah juga diharapkan memberikan informasi yang sama kepada ibu remaja agar tidak ada kebingungan pada diri ibu remaja.

Informasi yang berbeda dapat menimbulkan keraguan pada ibu remaja sehingga dapat menyebabkan ibu remaja mudah menyerah dan dapat menghentikan pemberian ASI. Selain itu ibu remaja merasa malu untuk bertanya kepada orang lain termasuk tenaga kesehatan sehingga mengandalkan informasi dari keluarga. Informasi yang tepat dan sesuai dari keluarga sangat membantu keberhasilan pemberian ASI eksklusif.

Beberapa dukungan yang tidak sesuai dengan harapan ibu remaja seperti mertua yang menyusuh minum jamu, nenek yang memijit 
payudara saat payudara bisul dan suami yang membelikan susu formula. Sementara anggota keluarga yang lain tetap membantu ibu remaja mempertahankan pemberian ASI eksklusif. Penelitian Schrag \& Schmidt-tieszen (2014) menjelaskan bahwa dukungan keluarga menurut partisipan bersifat positif dan negatif. Dukungan yang bersifat negafif menyatakan lebih baik hidup sendiri dibandingkan tinggal serumah dengan keluarga. Keluarga dianggap meningkatkan stress ibu remaja, nasehat keluarga membuat ibu remaja semakin terpuruk. Keluarga dideskripsikan serakah dan boros seperti memberikan alat-alat yang tidak dibutuhkan oleh bayi.

Pengalaman ibu kandung merupakan acuan dalam bertindak bagi ibu remaja. Ibu remaja dengan status primipara tanpa pengalaman sebelumnya akan mengalami berbagai keterbatasan. Kurangnya pengetahuan dan pengalaman praktek menyusui seperti berapa frekuensi menyusui, apakah tanda saat bayi sudah cukup menyusui dapat menyebabkan frustasi dan mudah menyerah pada ibu remaja. Karakteristik usia partisipan pada penelitian ini merupakan usia remaja yaitu dibawah usia 18 tahun dan memberikan ASI eksklusif hingga usia bayi enam bulan. Beberapa penelitian menjelaskan bahwa usia ibu yang masih muda dibawah 21 tahun merupakan kelompok usia yang menjadi perhatian utama dalam pemberian ASI. Biasanya pada usia ini angka pemberian ASI baik inisiasi menyusu dini maupun menyusui eksklusif masih sangat rendah (Forde \& Miller, 2010). Sehingga membutuhkan nasehat berupa pengalaman ibu kandung untuk memberikan ASI.

\section{KESIMPULAN}

Uraian tema-tema telah meggambarkan tujuan khusus yang ditetapkan. Dari tema pertama disimpulkan bahwa ibu remaja merasakan pentingnya dukungan keluarga selama memberikan ASI eksklusif. Ibu remaja menyatakan tanpa keluarga tidak mampu merawat bayinya sendiri tanpa dukungan keluarga. Dukungan yang diterima ibu remaja berbentuk dukungan instrumental, informasi, emosional dan penghargaan. Dukungan ini dirasakan bermanfaat bagi ibu remaja diantaranya keberhasilan memberikan ASI eksklusif, masalah dalam memberikan ASI teratasi dan meningkatkan percaya diri. Beberapa partisipan mengalami kendala dalam memperoleh dukungan keluarga berupa perbedaan informasi yang diperoleh, dukungan yang tidak sesuai harapan. Perbedaan informasi tentang menyusui dari keluarga yang dapat membingungkan ibu remaja.

Penelitian ini merekomendasikan kepada penyedia pelayanan kesehatan untuk memberikan informasi kepada ibu remaja dan didampingi juga oleh keluarga seperti pasangan, ibu kandung, mertua atau kerabat yang terdekat dengan ibu. Hal ini diperlukan karena ibu remaja masih tergantung kepada dukungan keluarga dalam perawatan bayi.

\section{UCAPAN TERIMAKASIH}

Terimakasih peneliti ucapkan kepada semua pihak yang telah mefasilitasi penelitian ini meliputi semua responden yang terlibat, pimpinan Puskesmas Kemuning dan Puskesmas Tajur Halang Kabupaten Bogor serta Jurusan Keperawatan Maternitas Fakultas Ilmu Keperawatan Universitas Indonesia.

\section{DAFTAR PUSTAKA}

Forste, R., \& Hofmann, J. P. (2008). Are U.S. mothers meeting the HealthyPeople 2010 breastfeeding targets for initiation, duration, andexclusivity? The 2003 and 2004 National Immunization Surveys. Journal of Human Lactation, 24, 278288. doi:10.1177/0890334408317617.

Feldman-winter, L., \& Shaikh, U. (2007). Optimizing Breastfeeding Promotion and Support in Adolescent Mothers. Journal Human Lactation, 23(4), 362-367. http://doi.org/10.1177/089033440730830 3

Forde KA, Miller LJ (2010), 2006-07 North metropolitan Perth breastfeeding cohort 
study: how long are mothers breastfeeding?. Breastfeed Rev,18(2), 14-24.

Friedman, M.M., Bowden, V.R., \& Jones, E.G. (2003). Family nursing reseacrch, theory and practice. New Jersey: Prentice Hall.

Grassley, J., \& Eschiti, V. (2008). Grandmother Breastfeeding Support: What Do Mothers Need and Want?. BIRTH, 35(4), 329-336.

Grassley, J. S. (2010). Adolescent mothers' breastfeeding social support needs. Journal of Obstetric, Gynecologic, and Neonatal Nursing : JOGNN / NAACOG, 39(6), 713-722. http://doi.org/10.1111/j.15526909.2010.01181.x

Hannon, P., Willis, S., Bishop-Townsend, V., Martinez, I., \& Scrimshaw, S. (2000). African-American and Latina adolescent mothers' infant feeding decisions and breastfeedingpractices: a qualitative study. Journal of Adolescent Health, 26(6), 399-407.

Hannula, L., Kaunonen, M. \& Tarkka, M.T. (2008) A systematic review of professional support interventions for breastfeeding. Journal of Clinical Nursing, 17, 1132-1143.

Hunter, B. L. (2008). Teenagers' experiences of postnatal care and breastfeeding. British Journal Of Midwifery, 16(12), 785-790.

Kanhadilok, S., \& McGrath, J. (2015). An integrative review of factors influencing breastfeeding in adolescent mothers. The Journal of Perinatal Education, 24(2), 119-128.http://dx.doi.org/10.1891/10581243.24.2.119.

Kementrian Kesehatan RI. (2013). Riset Kesehatan Dasar. Jakarta: Balitbang Kemenkes RI.
Kleiber, B. V, \& Dimidjian, S. (2014). Postpartum depression among adolescent mothers: A Comprehensive Review of Prevalence, Course, Correlates, Consequences, and Interventions. Clinical Psychology Science and Practice, 21, 48-67.

Lowson, K., Offer, C., Watson, J., Mcguire, B., \& Renfrew, M. J. (2015). The economic benefits of increasing kangaroo skin-to-skin care and breastfeeding in neonatal units : analysis of a pragmatic intervention in clinical practice. International Breastfeeding Journal, 1-12. http://doi.org/10.1186/s13006-015-00358

Maputle, M. S. (2006). Becoming a mother: teenage mothers' experiences of first pregnancy. Curationis, 29(2), 87-95.

Mercer, R. T. (2004). Becoming a mother versus maternal role attainment. Journal of Nursing Scholarship, 36(3),226-232.

Mcinnes, R. J., \& Chambers, J. A. (2008). Supporting breastfeeding mothers : qualitative synthesis. Journal of Advanced Nursing, 62(4), 407-427. http://doi.org/10.1111/j.13652648.2008.04618.x

Mogre, V., Dery, M., \& Gaa, P. (2016). Knowledge, attitudes and determinants of exclusive breastfeeding practice among Ghanaian rural lactating mothers. International Breastfeeding Journal, 11(12), 1-8. DOI 10.1186/s13006-016-0071-Z

Moran, V. H., Dykes, F., Burt, S., \& Shuck, C. (2006). Breastfeeding support for adolescent mothers: similarities and differences in the approach of midwives and qualified breastfeeding supporters. International Breastfeeding Journal, 1(23), 1-12. http://doi.org/10.1186/1746$\underline{4358-1-23}$ 
Nesbitt, S. a, Campbell, K. a, Jack, S. M., Robinson, H., Piehl, K., \& Bogdan, J. C. (2012). Canadian adolescent mothers' perceptions of influences on breastfeeding decisions: a qualitative descriptive study. BMC Pregnancy and Childbirth, 12(1), 149. http://doi.org/10.1186/1471-2393-12149

Ngum Chi Watts, M. C., Liamputtong, P., \& Mcmichael, C. (2015). Early motherhood: a qualitative study exploring the experiences of African Australian teenage mothers in greater Melbourne, Australia. BMC Public Health, 15(1), 873. http://doi.org/10.1186/s12889-015-22152

Schmidt-tieszen, A. S. A. (2014). Social support networks of single young mothers, 42(January), 315-327. http://doi.org/10.1007/s10560-013-03242

Schrag, A., \& Schmidt-tieszen, A. (2014). Social support networks of single young mothers. Journal Child Adolescent Social Work, 31, 315-327. http://doi.org/10.1007/s10560-013-03242

Spencer, B. (2012). A qualitative description of African American women's breastfeeding experience. Available from ProQuest Dissertations \& Theses Global. (1617973538). (UMI No. 3544848)

Tucker, C. M., Wilson, E. K., \& Samandari, G. (2011). Infant feeding experiences among teen mothers in North Carolina: Findings from a mixed- methods study. International Breastfeeding Journal, $6(1), \quad 14 . \quad$ http://doi.org/10.1186/17464358-6-14

Twantley,K.,Twamley,K.,Puthussery,S.,Hardi ng,S.,Baron,M.,Macfarlane,A.,

(2011).UK-born ethinic minority women and their experiences of feeding their newborn infant.Midwifery 27,595-602. 